\title{
Gender inequalities in the City of London Advertising Industry
}

\section{Annie Wang \& Louise Crewe, 2018}

\section{Abstract}

This paper explores gender relations in the City of London advertising industry. It argues that the gender imbalance in the highest ranking positions and the stifled career progression of women in the industry are a result of social, structural and institutional factors rather than individual choice, lack of 'talent' or the absence of mentors or appropriate role models. We discuss the organization and spatiality of the advertising industry in London, the significance of social networking within and beyond the firm, and problematise the notion that female childbearing and caring are the primary determinants of women's truncated career trajectories in advertising. The research reveals that whilst age, gender and domestic divisions of labour combine to reinforce occupational sexual divisions of labour in the advertising industry in London, these inequality regimes (Acker 2006) are amplified by the industry's precariousness, informality and requirements for flexibility. Attempting to explain away gendered divisions of labour solely on the basis of women's role in social reproduction deflects attention away from other key determinants of inequality, most notably the pace of advertising work and the geographical concentration of the industry within London. These are further accentuated by deep-rooted forms of homophily and homosociality - those unspeakable inequalities that call into question the dominant post- feminist rhetoric that 'all the battles have been won' (Gill, 2008). We analyse the ways in which homosociality has been crucial in maintaining insidious sexism which has made it very difficult for female creatives to obtain the most prestigious roles at work. Taken together, the organisation and geography of the sector, the rhetoric of buzz and egalitarianism, the 'motherhood myth' and the homophilic practices at work within advertising combine to create deep and enduring gendered inequalities. 


\section{Keywords}

London Gender Advertising Industry Homosociality Networking Clustering

\section{Introduction}

This paper focuses on gender and work in the advertising industry in London, a key sector in the United Kingdom's Cultural and Creative Industry (CCI) characterised by plurality and diversity of employment. The CCI policy aimed to reshape Britain's 'new economy' around the creative industries and offered the potential, at least, for a workforce characterised by diversity across gender, age, class, and ethnicity dimensions (Gill, 2014). The policy promised new forms of work characterised by 'buzz', energy and informal temporal rhythms. Some two decades on, research is suggesting that employment in the creative economy is dominated by workers from a very small demographic pool and that the sector is characterised by a persistent lack of diversity, equality and social mobility (Campbell and Khaleeli, 2017; Skillset 2011 2012). This paper contributes to that research base, focusing on gender and age-based forms of inequality within London's advertising industry. It offers an account of the nature and possible reasons for persistent gendered occupational segregation in the City of London's advertising industry. Occupational inequality in the creative professions has been noted for some years (Gill, 2002; Milestone 2016; Tatli and Ozbilgin, 2012) and the advertising industry is no exception (Broyles, 2015; Broyles and Grow, 2008; Grow and Broyles, 2011; Grow and Deng, 2014; Mallia, 2009). The lack of equality within the sector has been identified as both a waste of talent and resource, and a brake on organizational success. We argue that such inequalities have far serious and more pernicious impacts than this.

In this paper we argue that gender inequality in the advertising industry has far deeper and more protracted repercussions on both economic and social reproduction than much of the existing literature on sexual divisions of labour acknowledges. The research reveals that whilst 
age, gender and class-based divisions of labour combine to reinforce occupational sexual divisions of labour in the advertising industry in London, these inequality regimes (Acker 2006) are amplified by the industry's precariousness, informality and requirements for flexibility. Attempting to explain away gendered divisions of labour solely on the basis of women's role in social reproduction deflects attention away from other key determinants of inequality, most notably the pace and spatial concentration of advertising work. These are further accentuated by deep-rooted forms of homophily and homosociality - those unspeakable inequalities that call into question the dominant post- feminist rhetoric that 'all the battles have been won' (Gill, 2008, 2014). We analyse the ways in which homosociality has been crucial in maintaining insidious sexism which has made it very difficult for female advertising workers to obtain the most prestigious roles at work. We focus on three intersecting geographic, social and organisational axes of inequality - clustering, networking and relational proximity, the 'motherhood myth' and its allied model of the unencumbered male worker, and homophilic practices - to explain deep and enduring gendered inequalities within the advertising industry.

The world of advertising is a particularly insightful industry through which to explore contemporary issues of gender, power, work and space. It reveals with great acuity how media representations of increasingly empowered women in advertisements are profoundly at odds with the occupational composition of the advertising industry's workforce. The London advertising industry has been projected as a progressive industry in which women are "visible and equal. It was a meritocratic industry that sought out the brightest and most creative minds wherever they may lie" (Baxter, in Nixon, 1990: 10). Or was it? A closer look reveals that advertising production and consumption tell very different gendered stories. Whilst women continue to be the primary consumer group, this is in sharp distinction to employment in the advertising industry, which remains a decidedly white, middle class, male affair. The significance of the paper is two-fold. Firstly, it explores the factors that might explain the 
pronounced occupational gender divide in the industry that take us far beyond calls to develop the female 'talent' pool or to enhance competitiveness. It reveals that the nature of advertising work and the social practices that reproduce gendered occupational divisions of labour are giving rise to new, more subtle forms of sexism. This less visible set of sexist practices require workers to perform new, flexible, unencumbered labouring subjectivities, requiring them to be always on, always available, anytime, anywhere. This raises significant political and policyrelated questions. Secondly, the paper empirically verifies these explanations through a range of original primary interview and observational research methods.

The structure of the paper is as follows. Section 2 outlines our methodological approach. In section 3 we draw on theories of clustering, embeddedness, social networks and space to account for gendered occupational divisions in the sector. Here we look specifically at the cultural-economic organization of work in the advertising industry, its agglomeration in Soho, London and the significance of social networking within and beyond the firm. Section 4 explores the intersectionality of age, gender and class as determinants of women's career progression in the advertising industry. Drawing on Acker's study of inequality regimes in organisations (2006) this section reveals how a suite of heteronormative assumptions about 'motherhood' (Gill 2010) and the 'male provider and worker' serve to legitimate and naturalise organisational and domestic divisions within certain creative professions in the capital. In section 5 we analyse the ways in which homosociality has been crucial in maintaining insidious sexism that has prevented women, and in particular female creative workers, from obtaining the most prestigious roles at work.

\section{Methodology and empirical rationale}

The results presented emerge from a qualitative, feminist geographical methodology that involved semi-structured ethnographic interviews supported by visual analysis and secondary 
data. 24 senior women working in the advertising industry in London were interviewed over a four month period between July and October, 2015. Four of the interviewees were CEOs and fourteen were on the main board. Their ages ranged from early 20s to late $50 \mathrm{~s}$. All but one were white, five had been to independent school, five had been to Oxford or Cambridge University and almost all had a University degree (20/24). The women were in a range of relationships (single, married, living with partner, with and without children). All identified as heterosexual. All interviewees remain confidential and are referred to by their titles. This intensive interview work was supplemented by a one week period undertaking observational research at one London advertising agency that enabled first-hand insight and in-depth observation of the work surroundings, practices and spaces that would have been difficult to ascertain from interviews alone. This both enhanced and deepened our understanding of the industry and of the day to day lives of its employees. It also enabled the collection and analysis of visual images of the micro-geographies at play within agencies. Finally, a range of secondary data was used in the form of statistics gathered from industry reports and media publications. These include the Institute of Practitioners in Advertising (IPA) annual census compiled from information from all of their member agencies across the UK. The census has produced statistics on the gender breakdown in 37 out of 44 qualifying agencies (Campaign, 2016 ${ }^{1}$ ). Other secondary sources that were analysed include reports and campaigns by WACL, Bloom, She Says, Who's Your Momma, Token Man, DAWN, Futures, Creative Equals, The GirlHood, The AdMission and Creative Pioneers.

\begin{tabular}{|l|}
\hline Agency \\
\hline Above and Beyond \\
\hline Chalk Social \\
\hline Geometry Global \\
\hline GoodStuff \\
\hline Kinetic \\
\hline
\end{tabular}

\footnotetext{
${ }^{1}$ This includes those with either a billing of over $£ 200$ million or with over 200 employees.
} 


\begin{tabular}{|l|}
\hline Lowe Profero \\
\hline M\&C Saatchi \\
\hline Maxus \\
\hline McCann London \\
\hline MediaCom \\
\hline Mother London \\
\hline Mullen Lowe Group \\
\hline Reprise Media \\
\hline Saatchi \& Saatchi \\
\hline Starcom MediaVest Group, UK \\
\hline Talon Outdoor \\
\hline TBWA \\
\hline Vivid Brand \\
\hline WCRS \\
\hline
\end{tabular}

Table 1: List of London agencies where interviews were undertaken.

\begin{tabular}{|l|l|l|}
\hline Position & Duration & Method of Interview \\
\hline Account Planner & - & E-mail \\
\hline Business Director and Head of Out-of-Home & $30 \mathrm{~min}$ & F2F \\
\hline CEO - Co Founder & $50 \mathrm{mins}$ & Phone \\
\hline Chief Strategy Officer & 90 & F2F \\
\hline Chief Strategy Officer & $30 \mathrm{mins}$ & F2F \\
\hline Co - CEO & $30 \mathrm{mins}$ & Phone \\
\hline Digital Director & - & E-mail \\
\hline Director of Marketing & $50 \mathrm{mins}$ & F2F \\
\hline Ex ECD & $50 \mathrm{mins}$ & F2F \\
\hline Global CEO & $20 \mathrm{mins}$ & Phone \\
\hline Head of Investment & $35 \mathrm{~min}$ & F2F \\
\hline Junior Editor & $80 \mathrm{mins}$ & F2F \\
\hline Managing Director & $35 \mathrm{mins}$ & Phone \\
\hline Managing Partner & $30 \mathrm{mins}$ & Phone \\
\hline Marketing Content Director & $50 \mathrm{mins}$ & F2F \\
\hline New Business Manager & $50 \mathrm{mins}$ & F2f \\
\hline People Director & $80 \mathrm{mins}$ & F2F \\
\hline SEO Manager & $20 \mathrm{mins}$ & Phone \\
\hline Strategy Director & $30 \mathrm{mins}$ & Phone \\
\hline Strategy Director & $50 \mathrm{mins}$ & F2F \\
\hline Talent Coordinator & $20 \mathrm{mins}$ & F2F \\
\hline U.K Design Director & $50 \mathrm{mins}$ & F2F \\
\hline UK Group CEO & $15 \mathrm{mins}$ & Phone \\
\hline & & \\
\hline
\end{tabular}


Table 2: List of interviewees and duration.

Advertising is one of the key sectors in the creative industries, which have in turn been identified as growth engines for a $21^{\text {st }}$ century city (DCMS, 2008; Pratt, 2006). London has been described as a creative hub and the sector more generally has been credited with the capacity for high growth and the provision of fulfilling career trajectories that harness individual creativity, skills and talent (Knell and Oakley, 2007). Whilst there has been a great deal of work on London as a global city (Sassen, 2001; Florida, 2003) much of this global creative city literature rather hides the lived realities and social interactions of real women in specific places at particular times (although see McDowell, 1997). Figure 1 reveals the gendered career profiles within the advertising industry in 2016 and shows that women are severely under-represented within the upper echelons of creative occupations.

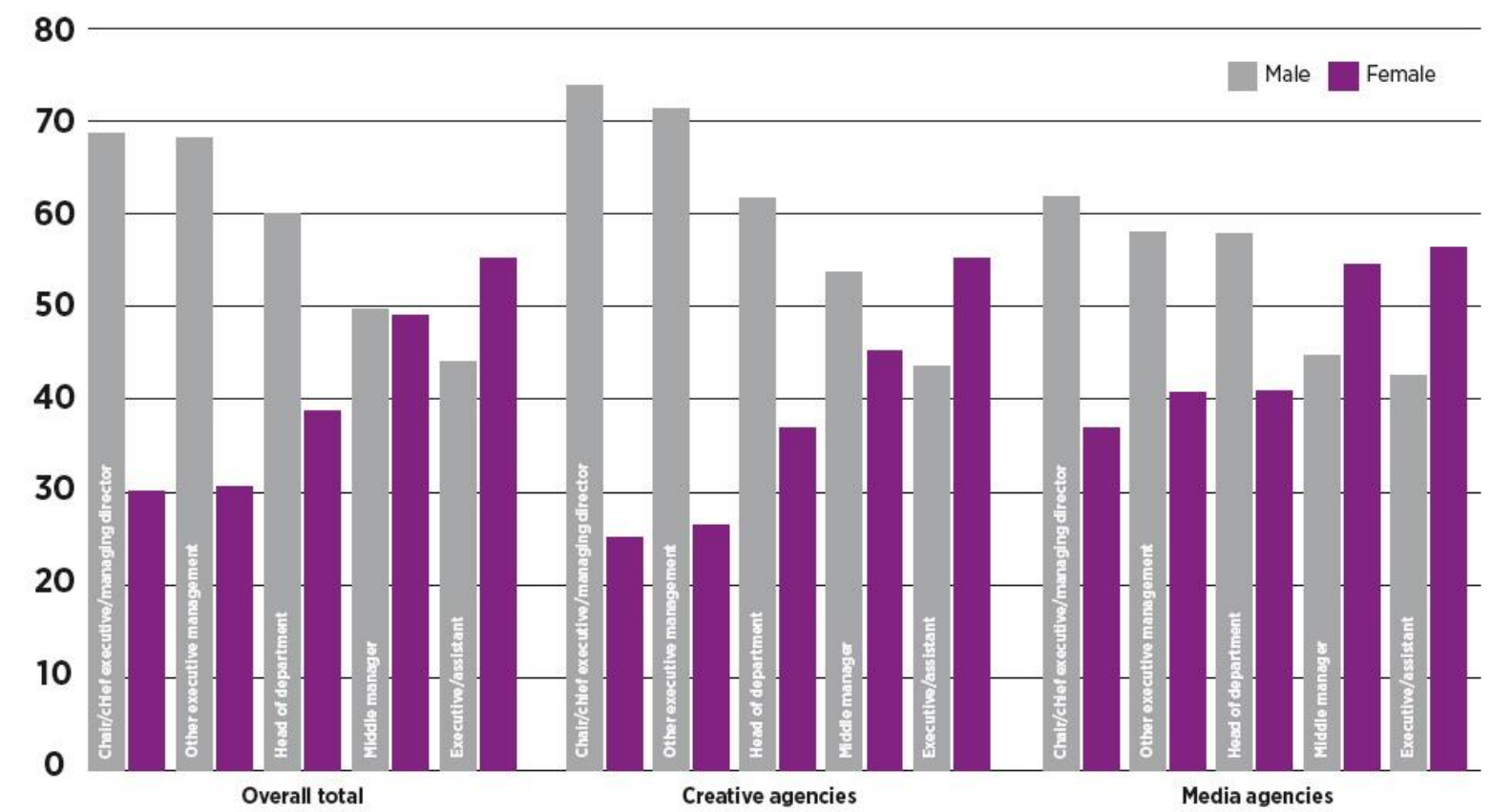

Figure 1: The percentage of employees by gender and seniority ${ }^{2}$

\footnotetext{
2 Figure 1 from Magee, (2016) This is adland 2016: Part 1: Gender. Available at http://www.campaignlive.co.uk/article/adland-16-part-one-gender/1379217
} 
This pattern of gendered occupational segregation is not new but is showing few signs of abating. Women currently account for just $27.3 \%$ of Senior Executive Management positions in UK advertising ${ }^{3}$. This occupational segregation is particularly problematic given that recruitment into the advertising sector is equitable by gender. In HR and secretarial roles women account for $85.4 \%$ and $94.3 \%$ of the advertising workforce (IPA, 2016). It is only as people move up the occupational hierarchy that the percentage of women declines (Magee, 2016). Industry organisations such as Campaign and IPA are calling for specific targets in relation to female employment, aiming for $40 \%$ of the most senior employment roles to be held by women (Campaign, 2016) arguing that "it is striking that as the roles become more senior, the gender split becomes considerably less balanced. While women account for 56.1 per cent of the junior agency roles, this drops to 39.2 per cent at the head of department level and 30.5 per cent in leadership positions" http://www.campaignlive.co.uk/article/adland-16-part-onegender/1379217\#TpA8mOCGiLTFBCeq.99. These figures illustrate an uncomfortable truth that currently prevails within agencies. There is a strong pattern of vertical and horizontal occupational segregation within advertising work: whilst women account for $50.8 \%$ of employees, they account for only $27.3 \%$ of senior positions (IPA, 2016). In the remainder of the paper we explore the factors that might explain the enduring gendered divisions within the advertising sector. The paper argues that contemporary advertising work is embodied, embedded and reproduced through discourse as well as practice (McDowell, 1999). Work spaces are not free from gendered social constructs; gender is a deeply ingrained embodied performance of 'stylized' repetitive 'acts' (Butler, 1988: 519). Work organisations are a critical location in the continuous creation of complex inequality regimes (Acker 2006) that are themselves co-constituted along age, gender and class dimensions.

\footnotetext{
${ }^{3}$ Senior Executive Management positions refer to Chair, CEO or Managing Director roles (IPA 2016).
} 


\section{Clustering, social networks and space in London's advertising industry: Unscheduled meetings in unlikely places}

The advertising industry is a key sector within the creative industries. It is heavily reliant on tacit knowledge which is best disseminated across different agents and networks via face-toface interaction (Storper and Venables, 2004; Leslie, 1995; Faulconbridge et al. 2010). This brings with it particular patterns of spatial and temporal interaction. Tacit knowledge is embedded, subjective and difficult to code and therefore is easier to exchange over short distances. Faulconbridge (2006) argues for the deconstruction of the tacit-local and explicitglobal binary of the geographies of knowledge since the 'social production of knowledge' entails a more complex relational and spatial dynamic. At a local scale the formation of tacit knowledge is enabled by organizational and relational proximity within an institution (Faulconbridge et al. 2010). As a result, there is an uneven geographical distribution of advertising agencies in the UK, as seen in Figure 2, with the majority locating in London (Storper and Venables, 2004), in a densely populated agglomerated area in Soho which Grabher (2002: 247) called 'ad village'.

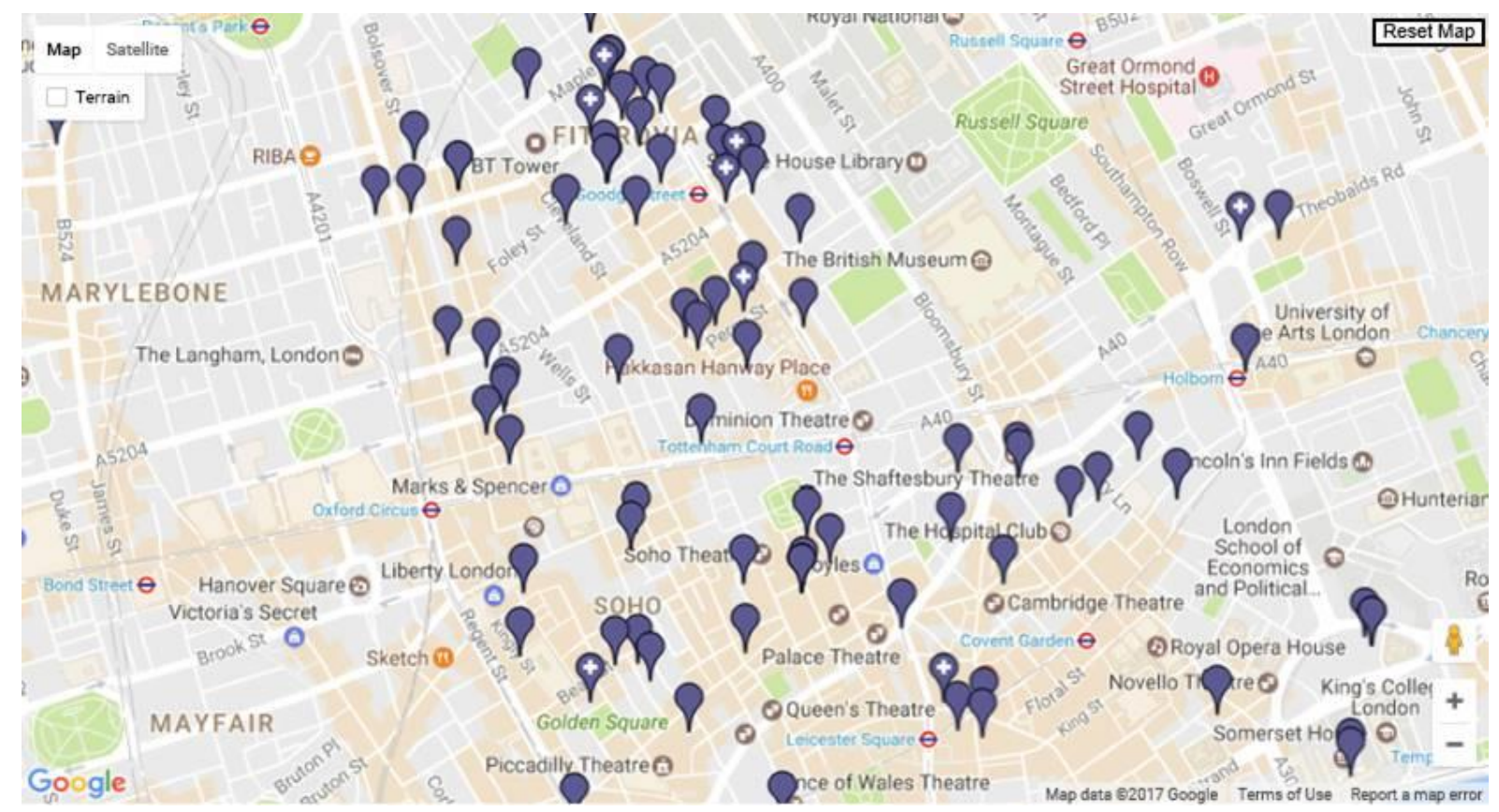


Figure 2. Distribution of advertising agencies in London ${ }^{4}$

This close proximity enables face-to-face interaction between and within organisations which generates trust and understanding that are vital for establishing relationships (Faulconbridge, 2006; Pratt, 2006). 'Ad village' enables what can be termed 'buzz' or 'noise' which is when face-to-face interaction over space creates a vibrant atmosphere where knowledge is passed and social groups exchange ideas (Storper and Venables, 2004). Buzz is prevalent in creative industries, particularly in global cities such as London, since tacit knowledge is communicated across space which is not neutral, but rather unstable, fluid and a product of social relations (Storper and Venables, 2004; Cronin, 2010; Faulconbridge et al. 2010; Faulconbridge, 2007). The advertising industry can be described as 'culturally and institutionally embedded' because of local market nuances and reflexive customers (Gertler, 2001, 2004; Lash and Urry, 1994). The ability of workers to succeed in the creative industries depends heavily on personal relationships, social networks and face-to-face contact. Economic action in advertising is inseparable from the social relations through which it is enacted (Granovetter, 1974). By studying the social dimensions of interactions through network formation within advertising it is possible to understand some of the factors that account for women's invisibility at the upper reaches of the industry (Clare, 2013; Grabher, 2001b; Neff et al. 2005; Ross, 2002). Creativity here takes place through 'geographies of circulation' (Thrift, 2000) in which social networks serve as a new form of labour market mediation (Brenner, 2002). Clusters of agencies in Soho enable networking, the sharing of knowledge and experience and a form of collective learning. The organization of work is facilitated by the spatial concentration of the sector and operation of dense informal networks. The project-based nature of advertising work is a heterarchic structure comprising institutional resources and networks that are locally embedded and multi-

\footnotetext{
${ }^{4}$ Figure 2 Available at http://www.ipa.co.uk/agencies
} 
layered.

Advertising-agency work is heavily dependent on this network sociality (McLeod et al 2011, Wittel, 2001), enacted in corporate, client-based and social spaces including bars, parties, launches and event awards where self-public relations, sociality and self-marketing holds particular prominence. The rhythms and spaces of such networks extend beyond the confines of the 9-5 regime and may pose particularly difficulties for workers with domestic caring responsibilities. This is a sociable industry, requiring attendance at inter and intra organizational work functions and events. Interviewees explained that 'I probably network more with industry peers and clients than I do with my colleagues at work ...you are definitely better at your job if you are attending industry events and getting to know people.' (CEO). The agency lifestyle can be unpredictable and tiring, long hours are often required and the various social functions afterwards can lead to tensions in employees' lives. These 'bulimic' work patterns (Pratt, 2002) involving "feast or famine, stop-go...periods of having to work all the time" (Gill, 2014) are deeply incompatible with raising a family. This may in part explain why women leave the industry at a young age and why there are fewer people over the age of forty or fifty in the industry (Clare, 2013; Grabher, 2004). Reflecting on the industry social life, one account director said that 'this industry is about working hard and playing hard. . you are constantly socializing. That is very much the norm.' This echoes work by Jarvis and Pratt (2006) who reveal the extensification and overflowing of work in the media industries and the impact that this has on both workers and households. The near-impossibility of managing the demands of a senior role in an advertising agency with raising a young family is clearly articulated by one interviewee Global CEO who reported 'I mean I'm probably out at least 3 nights a week for work so you know it's not a job for people who want to work 9 to 5 it's really important for us to be out with clients, to be out with colleagues to be out with media owners, to be at potential events where you are networking and meeting people and to build a profile.' 
Another explained how the extended times and clustered central-location spaces of the advertising world in central London impose particular constraints on women with children. Advertising workers feel compelled to network socially in order to succeed. As 'work' spills out into bars and restaurants both in and outside the firm, the distinctions between leisure time and work become increasingly blurred, as one interview discusses, "it's very important I mean I'm probably out at least 3 nights a week for work so you know it's not a job for people who want to work 9 to 5 it's really important for us to be out with clients to be out with colleagues to be out with media owners erm to be at potential events where you are networking and meeting people and to build a profile" (Global CEO). This is particularly problematic for workers who have domestic responsibilities in relation to social reproduction. It has been widely acknowledged that the culture of agencies and the industry is not conducive for a family life (Hochschild and Machung, 2012). One board member in this research explained how client-facing sectors organised around fast-paced and time-limited project-work pose particular problems for employees with children 'we recently had a global pitch and we just hadn't cracked it and our global CEO said we really, really, really need to get this right ... Friday, Saturday, Sunday and Monday a whole gang of people, they had a house in Spitalfields and everybody spent 4 days working on that pitch but if you had children or if you're a single mum you couldn't have of done it..." (Chief Strategy Officer). For women with childcare responsibilities such work rhythms would be very difficult to manage. As this example demonstrates, work in advertising can be sporadic, unpredictable and is undertaken under high levels of pressure and stress during unconventional working hours. This produces significant challenges for parents in the contemporary era. Such forms of sociality come at a cost and a price, and they require a heady mix of anxiety, excitement, fast pace and unconventional hours in central London locations - all the antithesis to the stable rhythms of social reproduction (feeding schedules, nursery and school openings times, children's bedtimes). The centrality of 
unpredictability and hedonism as working practises within the advertising industry in and around Soho is clear and does not sit easily with managing caring responsibilities and homework. What is much less clear is why it is predominantly mothers who face these constraints and challenges. The problem, it would appear, is rather more about gendered constructions of the successful, unburdened, always-on (male) advertising executive than it is about the lack of 'family friendly' policies of female role models. Children have little bearing on men's advertising careers but they actively hinder women's. It is to this that we turn in the next section.

\section{Problematising the Motherhood Myth: Regimes of inequality and the sexism that dare} not speak its name

Work in advertising is argued to be open, diverse, non-hierarchical and egalitarian. The images that circulate in relation to the sector portray it as open, exciting, meritocratic and progressive. The results from this research reveal a rather different reality - an industry that is cleaved through with gender and age inequality that is very much at odds with the pervasive representation of the advertising employee as enabled, unencumbered and creative. As we go on to describe, senior advertising positions are primarily occupied by middle aged men. For male executives, age is no barrier to promotion; for women it is. In this section we explore a number of 'inequality regimes' (Acker, 2006) that are evident in the advertising and that have been relatively unexplored in the literature (although see Mallia 2008, 2009). These inequality regimes are sustained through organisational controls that are diverse and complex. They are also bound up with internalised feelings of fear, anxiety and exclusion that accompany the performance of the creative professional worker-subject and that are increasingly difficult to articulate or challenge. Advertising is not a sympathetic place for women, particularly mothers, to work beyond the age of 40 . The extensification and intensification of executive work in the advertising industry are compounding long standing regimes of inequality based on gender. 
Gender effects are being mediated by other dimensions of inequality, specifically age and parental status. When women are experienced enough to strive for positions on the board it coincides with their childbearing years which disrupts the career trajectory of women far more so than men (Klein, 2000). This is important and requires further scrutiny.

This research reveals the additive effect of age on gender inequality within the sector. Respondents who had worked within advertising for 5 years or more said that it was ' $a$ young person's game' and that it was difficult to sustain when one has a family. One Managing Director explained that "lots of women drop out at like 35 and do something else...you eventually go 'I cannot be a good mother and do this' because you just can't. So the classic trajectory is that you have one kid and you have a second kid and then you can't afford to go back to work because your salary doesn't cover two lots of child-care... so people drop out around 32 or 35 once they've had 2 kids...You meet very few women... who have children, who are older". The work place culture in agencies appear to be a legacy of the traditional patriarchal domestic division of labour in which women are expected to raise the family and men to go out to work. Whilst shared paternity leave is a start, this is unlikely to challenge the structural pressures that mitigate against women reaching the highest levels in the advertising workforce. The contradictory challenges of being a mother in the private sphere and an employee in the public sphere leaves women experiencing an ambivalent and conflicted set of emotions. There is a culture which suggests that to prove commitment to the job and agency, workers are expected to be present and in the office. The contemporary creative worker must be "flexible, adaptable, sociable, self-directing, able to work for days or nights at a time without sleep and must be mobile, agile and without encumbrances or needs" (Gill, 2014: 516). In its current constitution, this new economy working subject cannot ever be ill, tired, pregnant, and must never need time off for caring. Such a construction is particularly prejudicial to women, as our research revealed "there are just fewer women who want to do the afterhours board 
meetings or the pre-hours breakfast and stuff like that because actually their family is more important" (Managing Partner). The question this raises is why fathers aren't equally invested in their parenting roles and seem to be able to have both a senior career and a family? A man with a child is seen as mature, balanced with "a bit of that elusive work-life balance" (Jackson, 2017). A woman is seen as risky, encumbered, potentially unavailable. Women are repeatedly asked "this stupid question. How can you manage private life and business? Nobody asks this question to men" (Iezzi 2005 in Broyles and Grow, 2008|: 5). As Catalyst president Sheila Wellington notes, "at the end of the day, many men head for drinks. Women head for the dry cleaners. Men pick up career tips; women pick up laundry, kids, dinner and the house (Rhode, 2003: 13; Disch et al. 2016). Whilst many of the interviewees are part of dual income households and 'share' childcare with their partners, it was widely acknowledged either implicitly or explicitly that women were the primary carer for their children: "I've got 2 kids you know they've seen less of me then they ought to... I know so many people who've, women who've dropped out really super smart women and...they're struggling to get a level of job that they're capable of getting so I think it's hard for everybody to be able to balance it" (CEO). This statement reveals clearly that there is an often unspoken gender bias at work, a baby penalty that hits women hard but so often goes unchallenged.

Women are particularly disadvantaged by geographical boundary crossing (between home and work, and between formal workplaces and informal networking spaces) (Conor et al. 2015). The impact of gendered ageism is felt keenly by women in the industry. Unlike their male counterparts, many women's career trajectories continue to be discontinuous, if not prematurely truncated, through pregnancy and child rearing. As a Managing Director described, 'so our agency...men and women that do the same role get paid the same amount of money. I know because I audited it. However, men on average earn more, which tells you what? Men are in more senior positions. Because women are still primary carer of children so eventually, 
when I have 2 kids or 3 kids I wouldn't be able to do this job anymore.' Women are assumed to have the majority of responsibility for home and children, something that is seldom expected from men (Bekkengen, 2002). Issues of workload and children are rarely questioned in relation to men's promotion; they routinely are for women. Our research suggests that little has changed in this respect in recent decades 'the agencies haven't changed the culture. I mean you're just not going to not see your children as a mother, and that's just not something you're prepared to do. I mean at the end of the day we're not saving lives, it's advertising (laughter)' (Ex ECD). Interviewees noted how age is a factor contributing to how people perceive women in the work place and is reflected in vertical occupational segregation in advertising. The age-division of labour is remarkably persistent, as one interviewee noted: I wrote my dissertation over 20 years ago on women in advertising...I was really shocked to find at the time that only $14 \%$ of board positions, senior positions in the ad world were women. I was shocked and thought this is meant to be an industry that's really forward thinking and future facing and so on versus banking or civil service and here I am years later and it's only at 25\% which I find quite depressing to be honest. (Co-CEO).

These examples reveal how an interweaving of age, gender and parental status have very specific occupational impacts for women in the senior reaches of the industry. Juggling a double life of home:work in London's advertising industry is difficult. These difficulties are primarily shouldered by women in the contemporary period. In spite of alleged informality and flexibility within the sector, a majority of advertising agencies in London "lack systems to make it easier to be a primary caretaker and creative worker, and most male creatives have stay-at-home wives to ease the burden (Weisberg and Robbs, 1997; Windels and Lee, 2007). The incompatibility of motherhood and creative success is captured clearly by one of the industry's most accomplished creative women, Nina DiSesa, former Chairman and Chief Creative Officer of McCann New York: "I wouldn't have this job if I had had kids" (Moore, 
2008). DiSesa argued that to succeed in the high-energy egocentric world of ad-land it is important to 'manage the unmanageable - men'. She achieved this through 'the art of S\&M seduction and manipulation', going on to write about her successes in the advertising world in a book entitled 'Seducing the Boy's Club: Uncensored Tactics from a Woman at the Top' http://adage.com/article/special-report-100-most-influential-women-in-advertising/womenadvertising-liberators/237163/.

These findings go far beyond existing research that suggest it is women's choice to opt out of pursuing a professional career, or that it is benign workplace neglect against mothers or a lack of suitable mentoring that account for sexual divisions of labour (Fuegen et al. 2004; Heilman and Okimoto, 2008; Mallia, 2008, 2009). This research reveals structural, institutional, organisational and embedded forms of discrimination. The intersectionality between gender, age, parental status and occupational upward mobility is particularly marked in the City of London given prohibitively high housing prices, childcare costs and the time and money required to commute. The times and spaces associated with home-work boundary crossing are long and expensive in London. One interviewee reveals how time-space constraints and childcare responsibilities are managed in her dual career professional advertising household: a nanny is employed - I'll come home and I'm very lucky in that my partner... we met at university so it never occurred to him that I wouldn't have a career and that it never occurred to me that he wouldn't be part of bringing up the children so he's home 2 nights of the week at 6 to release the nanny, I'm home 2 nights a week to release the nanny, 1 night we're both so you know we absolutely share that (Ex ECD). For many households the cost of employing a nanny would be prohibitive. For others who are required to travel and work irregular and unpredictable hours according to advertising agency norms, there is little guarantee that they could be home by $6 \mathrm{pm}$ two nights a week and maintain their career trajectory given the project based nature of agency work. Beyond this, the hiring of domestic staff to service the creative professional classes 
brings with it a suite of additional inequality regimes that may not be tolerable politically, socially and personally, even if they are economically. Taken together, the extensification of work and its tendency to spill out beyond the times and spaces of the conventional workplace act as specific brakes on career progression in advertising work. Whilst the need for more women in senior positions in the industry has been cast as a human resources or commercial problem, it is critically one of age and gender inequality founded upon deeply distorted power relations. Losing, or failing to promote, talented women to leadership roles after years of training and investment presents an economic problem. Much more than this, we argue, are the social and cultural implications of this research. Whilst losing talent is detrimental to competitiveness, it is argued here to be equally damaging to the specific career biographies of women in the advertising industry professions and more broadly to the possibilities for age and gender equality both at work and at home. Organising processes that reproduce inequality appear to becoming more subtle, diffuse and embedded. This makes them more difficult to challenge. Many inclusion and diversity policies (including 'family friendly policies which are primarily used by women with young families) are founded on the male model of organising and may in fact reinforce rather than undermine persistent gendering processes in the workplace.

Whilst this paper focuses specifically on the intersections of age, gender and parental status in accounting for occupational inequality, there is no doubt that these axes are in turn overlain by a suite of additional, and equally intractable, inequality regimes based on ethnicity, sexuality and disability. The advertising industry shows long-held recruitment preferences for applicants from independent schools and Oxbridge (see McLeod, O’Donohoe and Townley 2009). One of the agencies in this research operates an 'Oxbridge policy' and another Managing Partner revealed "it does tend to be, 'cause it tends to pick the best candidates and the best candidates tend to come from Oxbridge, you know. It's sad but true." One of our 
interviewees confirmed the strong class bias in recruitment practices in the industry, telling us how her agency 'adopted' $\mathrm{x} \& \mathrm{x}$ Oxbridge policy "I had Oxford on my CV and so he gave me an interview and he said do you know much about this and I said 'I don't know at all'. He said 'do you think an Oxbridge degree is any qualifications for this, what so ever' And I, I actually think I gave a very good answer ((laughter))." Compounding these class based distinctions are inequalities in relation to diversity and inclusion. The interviewees in this research observed the gulf between the rhetoric of meritocracy and inclusion, and its articulation in practice: "erm ethnicity is rubbish it's a real indignation I'd say our cultural representation as an industry is pretty rubbish and I think inevitably there are still issues with opportunities" (see too Grow 2016). One Director confirmed that networks and family connections act as key entry points into the sector, "there's still a lot of nepotism so it's mainly white, middle class, which is where it came from the traditional route because there's a lot of nepotism. There's oh my neighbour who lives next door to me they've got a son can he come in for some work experience or can he apply for the job erm that, that happens a lot in our industry". Taken together, the diffuse forms of inequality evident in the advertising industry call into questions the meritocratic myth of the creative industries. As Gill attests, the myth of equality is one of the key mechanisms through which inequality is reproduced" (Gill 2014: 524). It reveals the precise ways in which intersecting inequalities combine to multiply unequal outcomes on the basis of traditional categories of disadvantage (Tatli and Ozbilgin, 2012: 249).

\section{5. (Homo)Sociality \& space}

"At the top of our industry there is a closed loop of white guys, talking to white guys, about other white guys. And the problem is, we see no change, because the white men at the top, sitting pretty, have absolutely no desire to change...I am sick to death of talking about this because I find myself having to say the same thing over and over again. Fuck talking about it, fucking do it. My message to the male leaders of the industry is this: would you like to do less 
work and make more money? The moment you have $50 \%$ or more women on your board, on your leadership team, in your creative team and at the head of your creative department, you'll instantly make more money and do less work, because innovation, disruption and creativity are the result of diversity"(Cindy Gallop, CEO IfWeRantheWorld and former chair of BBH New York).

There is an evident privileging of certain forms of masculine subjectivity within creative departments. Accounts given by female creatives reveal a number of ways in which the links between success, promotion and creativity are exclusionary to women in the advertising industry. In part this is due to the unconventional and anti-social working hours discussed above. As long as potential women leaders and managers are excluded from (or constrained in their participation in) networked forms of male sociality both in the work-place and, crucially, beyond it at the margins of the clock (breakfast meetings, after-work drinks, parties), so they will be less likely to gain access to prestigious clients, projects and promotions (Cockburn, 1991; Hennig and Jardim, 1979; Morgan and Martin, 2006, Wajcman, 1988). The advertising sector is keenly aware of the disjuncture between its audience, its structure and its gendered occupational segregation: "It's 2016. The fact we're still talking about pay equality and the lack of women on boards astounds me... If agencies are to stay relevant, we need to keep up. Agencies should look like the people they market to, yet unconscious (or conscious?) bias still exists at the top of our industry. It's blind to suggest otherwise. The excuse "I'd give the job to a woman but none applied" doesn't cut it, and we must not accept it" (Rebekah Mackay Miller, managing director, trnd UK in The Drum, 2016). The peculiar and particular time and space rhythms of creative agencies constitute very real barriers to opening up senior creative work to gender equality. Beyond networking and the extensification of working hours there is clear evidence that certain forms of masculine homosociality within the senior ranks of the creative advertising industry are reproducing specific forms of gendered inequality. Homosociality 
refers to a series of practices in which men orient themselves towards other men within a patriarchal gender order. Gregory (2009) describes homosociality as formal and informal means of communication, including male networking, bonding, joking and dress codes. It includes formal 'old boys networks' and informal clubs, meetings and forms of communication, and is a key mechanism through which hierarchies of gendered occupational power are constructed, maintained and reproduced.

A range of research has shown how men in different settings reproduce constructions of hegemonic masculinity through collective storytelling, humour and banter (Barrett, 1996; Bird, 1996; Fawcett and Pringle, 2000; Gregory, 2009). In the specific case of the advertising industry, this research has revealed the advertising industry can be seen as an exclusive club with shared bonds and barriers to entry that combine to preclude women from its upper echelons. The rituals of beyond office life - pubs, clubs, bars, booze - are suffused with and atmosphere of informality, fun and relaxation that enables the creative spirit to fly. Further, the practices that re-create inequality are often subtle, unspoken and therefore difficult to both measure and challenge. Women interviewed as part of this research discuss how gender and class inequalities are enacted through talk and practice such that women's voices are rarely heard and at times literally silenced: 'a lot of boys that went to public school they're just good at speaking up and getting your voice heard'. Another one interviewee explained how gendered work-talk acts as an inequality device: 'I mean there's still like a whole bantery kind of thing... 'Oh it's banter'. No it's not, you're being an arsehole' (Marketing Content Director). Dishman has argued that "it's no secret to those in the industry that the upper echelons of the ad world are still very much a boys' club... Most people assume Mad Men is a quaint time capsule...The wardrobe has changed and there's no smoking and no bourbon, but if you really get down to the nitty gritty we haven't made nearly the progress we should." (2013). The dogged persistence of homosociality and misogyny were revealed by our research participants, one of 
whom argued “The same agency's studio used to bang on the tables if a pretty girl walked through. Like monkeys. It was shocking. Truly appalling. And incredibly disrespectful...

Everyone thought it was funny. As a woman, I found it totally un-funny, aggressive, demeaning and very intimidating. They were basically treating this girl as a sexual object, rather than as a colleague" (Digital Director). This echoes work by McDowell on gender in the City of London (1997) and Klein who revealed that "would-be male creatives felt obligated to play "their bloke card" and dial up the "football and babes talk" (p.29). The Digital Director further discussed one of her experiences thus: "The worst was at an ad agency in my first big job...I discovered all the men were discussing (on a daily basis) what underwear I was wearing - and in a detailed sense. It was horrible”.

Both the all-consuming nature of creative work and a macho organizational culture are widely cited factors preventing women from reaching the most senior positions (Broyles and Grow, 2008; Weisberg and Robbs, 1997). It is important to note that the operation of homosociality may be an unconscious, unreflexive practice embedded in organizational structures and cultures, enabling men to simultaneously reproduce male dominance in management while portraying themselves as pro-equality (Martin, 2001, 2006). The 2017 EOMA report reveals that a majority of surveyed women in advertising had dealt with unconscious and conscious bias and recognised the need for a 'work wife' who will take notes, plan the company party, order food. As one interviewee argues, "Yes - have been asked to get coffee. Have been asked to book meetings. Have been called 'Darling' in the office. Once the shock wears off - I tell them to fucking do it themselves".

Nixon acknowledges that many in senior positions in the industry say that they would like to recruit more women creatives and yet are locked into a way of thinking about creative jobs that are "shot through with gendered understandings of the creative person in advertising" (2000: 115). This extends to widely-held discourses about 'the creative' and a particular kind of 
assertive masculinity that presents as a "scripted persona, skilled in the art of self-presentation and with more than a hint of irreverence, unreasonableness and iconoclasm" (2000:107). Nixon describes how two young female creatives at Direct Arts, Samantha Jones and Miranda Harris were known in their department as "Beaver and Pussy" (2000: 107). Stereotyped views of advertising directors are perpetuated through masculine senior management cultures both through homosociality and homophily, which describes men's preference for men, particularly in top management positions. Studies of social networks use the concept of homophily to describe the frequently observed patterns wherein people who are socially similar are more likely to have relationships with each other. In more subtle ways informal exclusion and unspoken denigration remain evident in advertising workplaces and are difficult to document and confront (Acker 2006: 459).

Studies of managerial networks show that men's social networks are more homophilous than women's (Ibarra, 1992). Our research confirmed the 'for manager, think man' approach: "there were 4 men I was being assessed by and then they went to an advisory board of another 3 men so you know (the) man got the job ...if you're right at the top and there are no other senior women helping make the decision ...it's unlikely to be a women when everybody in the selection process is male" (Ex ECD). Gregory's work on homosociality in the locker room explains how, "gender and sexuality were used as weapons by those of the homogeneous culture to insult, ridicule and compete with the less well placed" (2009: 340). Banter may be a useful tool in fast-paced competitive environments, and the use of gender (or sexuality, race and class) to construct dominance is clear: "If the personal is fair game, then gender, sexuality, race, class and physical disabilities can be viewed as liabilities, especially when bantering with the dominant group on its terms" (2009: 341). As our research had highlighted, it is important to recognise the ways in which intersectionality influences the precise ways in which 
homosociality permeates through the creative world: gender never travels alone; other social power relations such as class, age and parental status also condition homosociality.

\section{Conclusion}

This research has revealed that the social networks, agglomeration economies, heteronormative views of gendered divisions in parenting, a male model of organising and embedded homosocial practises through which the advertising industry operates reproduce specific forms of occupational inequality. The research has shown that the particular forms of homosociality at work within the advertising sector are predicated on a conception of power as gendered and conditioned by the intersectionality of other social power relations, specifically age and parental status. These persistent inequalities are amplified by the precariousness, informality and requirements for flexibility that are widely noted features of contemporary creative workersubjectivity. In addition, new pressures around identity-making and self-presentation, as well as continuing difficulties related to homosociality and the need to manage parenting responsibilities mark the advertising industry out as being particularly difficult terrain for women to navigate and gain seniority. Patterns of presenteeism, long hours, and a male majority have become institutionalized in advertising agencies and show little sign of abating. This paper has revealed that although women currently enter the profession in equal numbers, they have been much less successful in reaching the higher echelons of the advertising world. In part this is the result of homosocial practices. In part it is due to informal social interactions that take place within but, critically, outside the formal spaces of the creative workplace. It is also undoubtedly to do with age and persistent gendered divisions of domestic labour: rarely, it seems, can women 'have it all'. In spite of postfeminist accounts of empowerment for women who can now 'consume their way' to freedom, this research has revealed how gender inequality is (re)produced in the advertising industry. It has shown how men perform their gender in ways which reproduces both hierarchy and occupational segregation at work, and gendered divisions 
of labour at home. The empirical work advances the theoretical concept of hegemonic masculinity and unchallenged sexism via an analysis of gendered working practices and the agency of individuals to resist such conventions. It reveals how advertising employment relies on long working hours, homosocial behaviour and subtle forms of sexism. Taken together, the examples from this research reveal how informal social networks can act as an exclusionary practice for women trying to juggle a double life of home:work. The intersectionality of age and gender in an industry dominated by project work and portfolio careers raises some significant challenges for the career trajectories of women in advertising. This has significant implications for understanding how hegemonic masculinities are created and perpetuated within creative workplaces in which subtle and often unacknowledged forms of sexism are becoming normalised. Challenging industry structures and embedded working practices that are as invisible and subtle and they are divisive is a significant challenge. 


\section{References}

Acker, J. (1990). Hierarchies, jobs, bodies: A theory of gendered organizations. Gender \& society, 4(2), 139-158.

Acker, J. (2006). Inequality regimes gender, class, and race in organizations. Gender \& society, 20(4), 441-464.

Advertising Age (2012). "Women in Advertising: The Liberators, September 24, http://adage.com/article/special-report-100-most-influential-women-in-advertising/womenadvertising-liberators/237163/. (Accessed January 6th, 2017).

Alvesson, M. (1998). Gender relations and identity at work: a case study of masculinities and femininities in an advertising agency. Human Relations, 51(8), 969-1005.

Amabile, T. M., Conti, R., Coon, H., Lazenby, J. and Herron, M. (1996). Assessing the work environment for creativity. Academy of management journal, 39(5), 1154-1184.

Barrett, F. J. (1996). The organizational construction of hegemonic masculinity: The case of the US Navy. Gender, Work \& Organization, 3(3), 129-142.

Baxter, M. (1990). Women in advertising: findings and recommendations. Study commissioned by the Institute of Practitioners in Advertising (IPA), London.

Bendick, M. and Egan, M. L. (2009). Research perspectives on race and employment in the advertising industry (pp. 34-35). Washington, DC: Bendick and Egan Economic Consultants.

Bendl, R. (2000). Gendering organization studies: a guide to reading gender subtexts in organizational theories. LTA, 3, 00 .

Bird, S. (1996) Welcome to the men's club: homosociality and the maintenance of hegemonic masculinity. Gender \& Society, 12(2), 121-32. 
Brenner, C. (2002). Work In The New Economy: Flexible Labor Markets In Silicon Valley. Oxford: Blackwell.

Broyles, S. J. and Grow, J. M. (2008). Creative women in advertising agencies: why so few "babes in boyland"?. Journal of Consumer Marketing, 25(1), 4-6.

Butler, J. (1988). Performative Acts and Gender Constitution: An Essay in Phenomenology and Feminist Theory. Theatre Journal, 40(4), 519-531.

Clare, K. (2013). The essential role of place within the creative industries: Boundaries, networks and play. Cities, 34, 52-57.

Cockburn, C. (1991) In the Way of Women. Ithaca, NY: ILR Press.

Conor, B., Gill, R and Taylor, S. (2015). Gender and creative labour. The Sociological Review, 63(S1), 1-22.

Crompton, R. and Harris, F. (1999) Employment, careers and families: the significance of choice and constraint in women's lives. In Compton, R. (ed.) Restructuring Gender Relations and Employment, pp. 128-49. Oxford: Oxford University Press.

Cronin, A. (2010). Advertising, Commercial Spaces and The Urban. London: Palgrave Macmillan.

DCMS Department for Culture, Media and Sport (2008). Creative Britain: new talents for the new economy. DCMS.

Dishman, L. (2013) Where are all the women creative directors? Fast Company 16/2/2013

Dishman, L. (2017) This is the state of gender diversity on boards around the world Fast Company 8/12/2017

Durbin, S. and Tomlinson, J. (2010). Female part-time managers: networks and career mobility. Work, Employment \& Society, 24(4), 621-640. 
Faulconbridge, J. R. (2006) Stretching tacit knowledge beyond a local fix? Global spaces of learning in advertising professional service firms. Journal of Economic Geography, 6(4), $517-$ 540.

Faulconbridge, J. R. (2007) Exploring the role of professional associations in collective learning in London and New York's advertising and law professional-service-firm clusters. Environment and Planning A, 39(4), 965-984.

Faulconbridge, J. R., Taylor, P., Nativel, C and Beaverstock, J. (2010) The globalization of advertising: Agencies, cities and spaces of creativity. London: Routledge.

Fawcett, R and Pringle, J. K. (2000) Women CEOs in New Zealand: where are you?. Women in Management Review, 15(5/6), 253-260.

Fuegen, K., Biernat, M., Haines, E. and Deaux, K. (2005) Mothers and Fathers in the Workplace. The Economist, 376(8436), 63-65.

Gertler, M. (2001) Flows of People, Capital and Ideas. ISUMA, Automne.

Gertler, M. S. (2004) Creative Cities: What are they for, How do they work, and How do we Build Them?. Ottawa: Canadian Policy Research Networks.

Gertler, M. S. (2004) Manufacturing culture: The institutional geography of industrial practice. Oxford: Oxford University Press.

Gill, R. (2002) Cool, creative and Egalitarian? Explore gender in project-based new media work in Europe. Information, communication \& society, 5, 70-89.

Gill, R. (2008) Empowerment/sexism: Figuring female sexual agency in contemporary advertising. Feminism \& Psychology, 18(1), 35-60. 
Gill, R. (2014) Unspeakable inequalities: Post-feminism, entrepreneurial subjectivity and the repudiation of sexism among cultural workers Social Politics 21(4) 509-528

Grabher, G. (2001a) Ecologies of creativity: the Village, the Group, and the heterarchic organisation of the British advertising industry. Environment and planning A, 33(2), 351- 374.

Grabher, G. (2001b) Locating economic action: projects, networks, localities, institutions. Environment and Planning A, 33(8), 1329-1331.

Grabher, G. (2002) The project ecology of advertising: tasks, talents and teams. Regional studies, 36(3), 245-262.

Grabher, G. (2004) Learning in projects, remembering in networks? Communality, sociality, and connectivity in project ecologies. European urban and regional studies, 11(2), 103-123.

Granovetter, M. (1995) 1974, Getting A Job: A Study of Contacts and Careers. Cambridge, MA: Harvard University Press.

Gregory, M. R. (2009) Inside the locker room: male homosociability in the advertising industry. Gender, Work \& Organization, 16(3), 323-347.

Grow, J. (2015) $3 \%$ is now $11 \%$ or maybe $14 \%$. These numbers are appalling Grow Cultural Geography Blog 16/6/2015

Grow, J. (2016) Ad Land Lacks Diversity Grow Cultural Geography Blog, 14/3/2016

Grow, J. M. and Broyles, S. J. (2011) Unspoken rules of the creative game: Insights to shape the next generation from top advertising creative women. Advertising \& Society Review, 12(1).

Grow, J. M. and Deng, T. (2014) Sex segregation in advertising creative departments across the globe. Advertising \& Society Review, 14(4). 
Groysberg, B. (2008) How star women build portable skills. Harvard Business Review, 86(2), 74.

Hackley, C and Arthur J.K. (2007) The trouble with creatives: negotiating creative identity in advertising agencies. International Journal of Advertising, 26(1), 63-78.

Heilman, M. E. and Okimoto, T. G. (2008) Motherhood: a potential source of bias in employment decisions. Journal of Applied Psychology, 93(1), 189-98.

Hennig, M. and Jardim, A. (1979) The Managerial Woman. London: Pan.

Hochschild, A. R and Machung, A. (2012) The second shift: Working families and the revolution at home. New York: Penguin.

Hochschild, A. R. (2012) The managed heart: Commercialization of human feeling. Berkeley: University of California Press.

Holgersson, C. (2013) Recruiting managing directors: Doing homosociality. Gender, Work \& Organization, 20(4), 454-466.

Ibarra, H. (1992) Homophily and differential returns: sex differences in network structure and access in an advertising firm. Administrative Science Quarterly, 37(3), 422-47.

IPA. (2016) IPA Census 2015, 1-20.

Fullerton, J. A. and Kendrick, A. (2014) Perceptions of work/life balance among US advertising students: A study of gender differences. Advertising \& Society Review, 14(4).

Jackson, E. (2017) Damned if you do...Banal gendered exclusions in academia, babies and 'dinner with other candidates' Sociological Review Blog, 26 July 2017 
Jarvis, H. and Pratt, A. C. (2006) Bringing it all back home: The extensification and 'overflowing' of work: The case of San Francisco's new media households. Geoforum, 37(3), 331-339.

Kay, K and Shipman, C. (2014) The confidence gap. The Atlantic, 14, 1-18.

Kilduff, M. and Mehra, A. (1996) Hegemonic masculinity among the elite. In Cheng, C. (ed.) Masculinities in Organizations, pp. 115-29. Thousand Oaks: Sage.

Klein, D. (2000) Women in Advertising - Ten Years On. London: IPA.

Knell, J. and Oakley, K. (2007) London's creative economy: an accidental success?.

Lash S. and Urry J. (1994) Economies of Signs And Spaces. London: Sage.

Leslie, D. (1997) Abandoning Madison Avenue: the relocation of advertising services in New York City. Urban Geography, 18(7), 568-590.

Leslie, D. (1997) Flexibly specialized agencies? Reflexivity, identity, and the advertising industry. Environment and Planning A, 29(6), 1017-1038.

Leslie, D. A. (1995) Global scan: The globalization of advertising agencies, concepts, and campaigns. Economic Geography, 402-426.

Magee, K. (2016) This is adland '16: Part one: Gender [online]. Campaign. Available at: http://www.campaignlive.co.uk/article/adland-16-part-one-gender/1379217 [Accessed 18th January 2016]

Mallia, K. (2009) Rare birds: Why so few women become ad agency creative directors. Advertising \& Society Review, 10(3). 
Mallia, K.L. and Windels, K. (2011) Will Changing Media Change the World? An Exploratory Investigation of the Impact of Digital Advertising on Opportunities for Creative Women, Journal of Interactive Advertising, 11(2), 30-44.

Martin, P.Y. (2001) 'Mobilizing masculinities': women's experience of men at work. Organization, 8(4), 587-618.

Martin, P.Y. (2006) Practicing gender at work: thoughts on reflexivity. Gender, Work \& Organization, 13(3), 254-76

McDowell, L. (1997) Capital Culture. Gender at Work in the City. Oxford: Wiley - Blackwell.

McDowell, L. (1999) Gender, identity and place: Understanding feminist geographies. Minneapolis: University of Minnesota Press.

McKinsey \& Company (2015) Women in the Workplace 2015. Lean in, 1-30.

McLeod, C. O’Donohoe, S. and Townley, B. (2011) 'Pot Noodles, Placements and Peer Regard: Creative Career Trajectories and Communities of Practice in the British Advertising Industry.' British Journal of Management 22, no. 1 114-31.

McLeod, O’Donohoe, S. and Barbara Townley, B. (2009) 'The elephant in the room? Class and creative careers in British advertising agencies' Human Relations

Moore, B. (2008) "60 Seconds with Nina DiSesa," New York Post, February 11, http://www.nypost.com/p/ seconds_with_nina_disesa_oN2nRjUGFCpbmX0TUnrdtO [accessed January 17, 2016].

Morgan, L.A. and Martin, K.A. (2006) Taking women professionals out of the office: the case of women in sales. Gender \& Society, 20(1), 108-28. 
Neff, G., Wissinger, E. and Zukin, S. (2005) Entrepreneurial labor among cultural producers: "Cool” jobs in "hot" industries. Social semiotics, 15(3), 307-334.

Panel on Fair Access to the Professions (PFAP) (2009) Unleashing aspiration: the final report of the panel on fair access to the professions. London: Cabinet Office, available online at www.cabinetoffice.gov.uk/media/227102/fair-access.pdf.

Pinnington, A. H. and Sandberg, J. (2013) Lawyers' professional careers: increasing women's inclusion in the partnership of law firms. Gender, Work \& Organization, 20(6), 616-631.

Pratt, A. C. (2006). Advertising and creativity, a governance approach: a case study of creative agencies in London. Environment and planning A, 38(10), 1883-1899.

Rhode, D. L. (Ed.) (2003) The Difference" Difference" Makes: Women And Leadership. Palo Alto, CA: Stanford University Press.

Roper, M. (1996) 'Seduction' and 'succession': circuits of homosocial desire in management. In Collinson, D. and Hearn, J. (eds) Men as Managers, Managers as Men. Critical Perspectives on Men, Masculinities and Management, pp. 210-26. London: Sage.

Ross, A. (2002) No-collar: The humane workplace and its hidden costs. New York: Basic Books.

Sassen, S. (2001) The Global City Princeton University Press

Smithson, J. and Stokoe, E. H. (2005) Discourses of Work-Life Balance: Negotiating 'Genderblind' Terms in Organizations. Gender, Work \& Organization, 12(2), 147-68.

Storper, M. and Venables, A. J. (2004) Buzz: face-to-face contact and the urban economy. Journal of Economic Geography, 4(4), 351-370.

The 3\% Conference (2014) Female CDs on the Rise, A Study of Women serving advertising 
Creative Directors, 1 -12.

The 3\% Conference (2017) The Elephant on Madison Avenue EOMA White Paper The 3\% Conference

The Drum (2016) Vox Pop: The gender fall out in today's ad land, http://www.thedrum.com/opinion/2016/08/05/vox-pop-gender-fall-out-today-s-ad-land (Accessed February 9th 2017).

Thrift, N. (2000) Performing cultures in the new economy. Annals of the Association of American Geographers, 90(4), 674-692.

Wajcman, J. (1998) Managing Like a Man. University Park, PA: The Pennsylvania State University Press.

Weisberg, L. and Robbs, B. (1997) Creative Department Still boys' Playground. Advertising Age, 68(47), 28.

Weisberg, L. and Robbs, B. (1997b), "A Study of the Underrepresentation of Women in Advertising Agency Creative Departments," paper presented at the Association for Education in Journalism and Mass Communication.

Wharton, A. and Bird, S. (1996) Stand by your man. Homosociality, work groups and men's perceptions of difference. In Cheng, C. (ed.) Masculinities in Organizations, pp. 97-114. Thousand Oaks: Sage.

Windels, K. and Lee, W. N. (2007) "An Exploration into the Representation of Female Creatives in Today's Advertising Agency," paper presented at the Annual Conference for the American Academy of Advertising, Burlington, VT.

Windels, K. (2011) What's in a Number? Minority status and implications for creative professionals. Creativity research journal, 23(4), 321-329. 
Windels, Kasey, and Wei-Na Lee (2012) 'The Construction of Gender and Creativity in Advertising Creative Departments.' Gender in Management: An International Journal 27, no. 8 $502-19$.

Wittel, A. (2001) Toward a network sociality. Theory, culture \& society, 18(6), 51-76.

Witz, A. and Savage, M. (1992) The gender of organizations. In Savage, M. and Witz, A. (eds) Gender and Bureaucracy, pp. 3-62. Oxford: Blackwell.

World Economic Forum (2016) The Global Gender Gap Report World Economic Forum 